UDC 657.421.32

JEL Classification: M10, M40, M41

http://doi.org/10.21272/mmi.2018.4-04

Zenovii-Mykhailo Zadorozhnyi,

D.Sc., Professor, Ternopil National Economic University, Ukraine

Yuliya Sudyn,

Ph.D., Ternopil National Economic University, Ukraine

Volodymyr Muravskyi,

Ph.D., Associate Professor, Ternopil National Economic University, Ukraine

\title{
GOODWILL ASSESSMENT IN ENTERPRISE MANAGEMENT: INNOVATIVE APPROACHES USING COMPUTER AND COMMUNICATION TECHNOLOGIES
}

Abstract. It is substantiated that goodwill is an integral part of the company and a special kind of intangible asset that brings the company additional profits and contributes to the growth of competitiveness. It is proved that the management of the goodwill value and the ability to reliably evaluate it are the priorities of the company's managers, and the development of computer-communication accounting forms introduces new adjustments in the ways and methods for evaluating the intangible assets of the enterprise. The purpose of the article is to analyse the existing methods of evaluation and consider fundamentally new approaches to the use of computer technologies in developing an innovative method for determining the value of goodwill as a set of non-material benefits of the enterprise. The article uses historical-logical and economic-mathematic methods for analysing existing approaches to goodwill evaluation, generalization and comparison to justify a market approach with the use of communication technologies as an innovative method of goodwill assessment. The advantages and disadvantages of each of the relevant approaches to determining the value of an intangible asset are identified. It is proved that the income method considers goodwill as a generator of future income of the company, which allows orienting the user to future company results, but when it is used, it is not possible to assess the existing goodwill from enterprises where there is a loss in the current activity. The use of cost method, which is considered to be the most popular, is analysed, since it allows taking into account expenses that make up the value of the asset and is labour-free, but the inability to quickly estimate the situation on the market and to compare the intangible benefits with competitors is its disadvantage. It is noted that the lack of a market approach is the insufficient data transparency on the value of intangible components of goodwill, but the use of computer programs and Internet technologies, as the determining factors in improving the efficiency and reliability of the evaluation, make it most justifiable. The paper concludes that using a market-based approach to goodwill assessment will contribute to minimizing financial and time resources for evaluation, as part of the functions will be implemented by a computer program; optimization of information flows, which is determined by the use of communication channels, increase in the reliability of the assessment, which is associated with an operational reaction to external changes that affect the company.

Keywords: valuation, intangible assets, goodwill, enterprise management, innovation, a computercommunication form of accounting.

Introduction. The efficiency of an enterprise depends on the correct assessment and accounting of all assets of the company. At the present stage of society's development, intangible resources play a special role in the ability to influence the size of the company's profit and its position on the market. In particular, a special kind of intangible asset is goodwill, which reflects the value of the business reputation of the enterprise. The expediency of its registration is the subject of discussions of scientists both in Ukraine and abroad. The greatest interest is the definition of goodwill valuation methods and its reflection in the company's accounting and analytical system.

Taking into account the market conditions of economic activity and considerable competition, an enterprise must be able to determine the value of its own goodwill. Given the importance of goodwill assessment, we will outline the main reasons for its implementation:

Cite as: Zadorozhnyi, Z.-M., Sudyn, Y. \& Muravskyi, V. (2018). Goodwill Assessment in Enterprise Management: Innovative Approaches Using Computer and Communication Technologies. Marketing and Management of Innovations, 4, 43-53. http://doi.org/10.21272/mmi.2018.4-04 
1. For the purpose of the management (level of management, professionalism of managers and competence of the personnel).

2. Determine the level of the intellectual capital of the company.

3. Assessment of the enterprise value before the sale agreement, which will take into account unrecorded intangible benefits.

4. Confirmation of the sales value after the transaction of purchase of the enterprise.

5. During the implementation of the mergers and acquisitions of economic entities (justification of fair value).

According to UAS 19, the residual value approach is used to determine the value of goodwill. The difference between the acquisition price and the fair value of assets, fewer liabilities and contingent liabilities, is determined [19]. The method for assessing goodwill at residual value was first considered in professor J. Kenning's research, which defined goodwill as the main account for displaying residual value [2, p. 155]. According to his point of view, each company's asset must be reliably estimated, since it has an impact on the cash flows and the generation of profits. Therefore, the definition of the value of an enterprise is associated with the valuation of assets. In this case that the true value of all assets remains unallocated, then the resulting difference should be recognized as goodwill. In the opinion of J. Kenning, goodwill is part of the firm's value, which cannot be attributed to any of the existing assets [2, p. 112].

The condition for the existence of a positive difference between the fair value of the assets of an enterprise and the price of its acquisition may not always be recognized as an asset (goodwill) or evidence of the existence of intangible benefits. There is always a risk of unreasonable overpayment for an enterprise due to subjective reasons. They are the following:

- lack of knowledge of the participants in the transaction regarding the real company's market value;

- company's acquisition to form monopolies (justified overpayment);

- the problem of determining the fair value of identifiable assets, liabilities and contingent liabilities;

- inflation trends leading to overpayment with the condition of an expected increase in the company's price.

As for the formation of a negative difference, which is recognized as the income of the reporting period, there are also factors that cause an unjustified understatement of the enterprise price. In particular, they are the ability to bargain, an excess of fair value of assets, an undervalued fair value of obligations and contingent liabilities, market imperfections, etc.

It should be noted that in the legal regulatory framework for goodwill accounting, both in domestic and international practice, there are no clear characteristics for determining the conditions under which arises goodwill or profits from a profitable acquisition. Therefore, the technical recognition of the considered concepts in the accounting if the difference between the purchase price and the buyer's share in the fair value of purchased identifiable assets, liabilities and contingent liabilities on the date of acquisition of the enterprise is groundless and contradicts the principles of displaying information in accounting.

In order to solve the problems, it is necessary to consider the existing approaches and determine the methods of goodwill valuation, which will allow the most reliable representation of information about the intangible benefits of the company.

Analysis of recent researches and publications. The goodwill as an asset is the complexity of identifying, evaluating and separating from the enterprise and other types of intangible assets. It reflects the benefits that make it possible for an enterprise to generate additional revenues in the industry where it operates without causing additional costs. Therefore, V. Travin's opinion is that due to the lack of an adequate basis that will enable comparisons and the inherent uniqueness of the vast majority of intangible assets to be comparable, they will be more likely to be compared to art than science [22, p. 193].

The leading experts of the international consulting company "2K Audit" determine surplus profit and balance method as priority methods of goodwill evaluation [17]. 
The well-known economist M. Puzynia adheres to the position of goodwill evaluation by the following methods: accounting, a method of surplus profits, assessment of business reputation through the indicator of business activity, analytical method of business reputation [20, p. 43-44].

The researchers H. D. Ping, B. Di conventionally divide the well-known methods of goodwill assessment into two groups: qualitative and quantitative. The first group includes the following methods of valuation: the method of surplus profits, the accounting method of calculating goodwill, the method of Brand Finance, the method of measuring goodwill using the multiplier M [7, p. 149]. The methods are based on the goodwill valuation. The second group forms methods based on the quantitative assessment of goodwill: the method of sociological surveys, rating method, expert, statistical and advisory methods. Such a division is quite acceptable and allows us to evaluate goodwill as a notion of value, taking into account the qualitative characteristics. We believe that users according to the information needs can choose the method that will be most appropriate in a particular situation while weighing the advantages and disadvantages of each assessment method.

V. Travin suggested the structured approach, which examines methods for assessing goodwill through the prism of interdisciplinary approaches, dividing them into four groups:

1. In accordance with the requirements of accounting (the method of additional cost-gaining or the method of additional profit; the approach based on taking into account the results of certain actions; an approach based on exceeding the purchase value of the assets received at their current fair price; the method accordingly to "Provisions of the expert assessment of intangible assets", according to which the expert assessment of the value of intangible assets, including goodwill, not reflected in the balance sheet, may be determined as a balance sheet profit of the enterprise after taxation and the capitalization rate minus the value of the integral property complex on the balance sheet.

2. In accordance with the requirements of international financial reporting standards (measurement method at actual cost, which provides for further testing of goodwill for impairment).

3. In accordance with the needs of financial management (valuation method, taking into account the volume of sales, the qualimetric method of measuring goodwill, the method of surplus profit, the statistical method of goodwill evaluation, the binomial method, D. Tobin's ratio).

4. In accordance with the needs of management (managerial staff) (method of sociological surveys, an expert method that enters rating and offering).

0 . Tradler defines three approaches to measuring the value of internal goodwill: the assessment of the company's reputation; the method of residual value, which reflects the excess of the business price as a whole over the overall estimate of the net value of its tangible and intangible assets; discounted approach to assessing the current difference between expected future profits and standard returns on all company assets, excluding goodwill [9].

P. Bilyavskyi maintains the position of the need to reflect the internal goodwill in accounting and proposes the following methods for its valuation: the method of cost of the trademark, the alternative method, the residual method, the calculation of $D$. Tobin's ratio, the method of surplus profits, goodwill measurement by the indicator of business activity [1, p. 312-313].

Scientists L. Wilkin, J. Campbell, S. Moore and J. Simpson consider goodwill through the prism of its elements (reputation, prestige of brands, constant customer base) and proposes to define it traditionally as the difference between the value of the enterprise as a whole and its real assets (capital) [11, p. 42].

The economic literature proposes three approaches to the valuation of intangible assets, in particular, goodwill and intellectual capital. Authors such as A. Andriievskyi [12], J. Hadavska [3], A. Vasarheli, A. Kohan, M. Tutl [10], L. Miller [5] distinguish income, expense and market approaches, which include appropriate assessment methods.

Selection of previously unsettled parts of the general problem. Studies devoted to the evaluation of goodwill address commonly accepted methods and methods for its implementation. However, the 
dynamics of the development of computer programs and automation of accounting creates new challenges aimed at increasing the efficiency of data and taking into account external and internal factors of influence on the enterprise. In view of the above, it is necessary to analyze the existing approaches to goodwill assessment and to develop ways of improving them.

The main aim. Explore existing goodwill valuation methods and propose innovative approaches to its implementation, taking into account the dynamics of the development of computer-communication accounting forms, to provide management with high-quality and relevant information about the company's intangible benefits.

The basic material. The income approach is based on the use of a causal link between the functional characteristics of the intangible goodwill elements and the expected revenues from their use. Goodwill's estimation within the framework of the income approach is based on the methods based on calculations of the average sums of profit, additional profit, sales volume.

The method based on the calculation of the average sums of profit was first considered in the writings of I. Blanc [13, p. 420]. It is based on the assertion that goodwill is the company's surplus profit from the total useful use of synergies. It is assumed that the revenues from the sharing of resources are significantly higher than the amount of income, from the use of the same resources in a separate form.

The method based on the calculation of excess resources, to calculate the goodwill cost uses the following formula:

$$
\mathrm{GW}=\left(\frac{N I}{\mathrm{RCA}}-T A\right) \times W
$$

where GW is goodwill; $N I$ - net profit; RCA - profitability of total assets; $T A$ - the value of total assets; $W$ - share of own funds in the structure of liabilities of the enterprise [15].

In the study, Samsonov proposed to calculate goodwill by using the surplus profit formula:

$$
\mathrm{GW}=\frac{N O I-N A \times e}{\mathrm{Rg}}
$$

where GW - is goodwill; NOI - net operating income; NA - the value of net tangible assets; $R e$ - capitalization of net income from the main activity; $\mathrm{Rg}$ - capitalization factor of intangible assets [21].

The formulas considered have shown that goodwill is calculated as the difference between net profit and the amount of medium-size income from the assets of the enterprise. As a rule, in enterprises, the value of assets exceeds net profit. However, this feature does not mean that goodwill should be negative. The methods discussed do not involve the calculation of the discount rate, so the use of formulas based on the calculation of the average sums of profit and surplus profits to calculate the goodwill need enhanced control of financial managers.

Application of the method, which involves the calculation of products sales, involves the calculation of the profitability of goods sales, describing the share of net profits in the volume of sales.

The considered method involves the use of the formula:

$$
\mathrm{GW}=(\mathrm{NOI}-\mathrm{Qf} \times \mathrm{Rq}) / \mathrm{Rg}
$$

where NOI is the net operating income of the company. Calculated as gross income less operating expenses and expenses for reimbursement (for current repairs); Qf - the cost of sold products (goods, works, services); $\mathrm{Rq}$ - medium-term profitability ratio of sales; $\mathrm{Rg}$ - is the capitalization factor of intangible assets (the ratio of company profits to the value of intangible assets shown in the balance sheet) [8]. 
The product of the average annual volume of product sales to the medium-term profitability ratio shows the amount of annual average net industrial income. Another deduction from the average annual net profit of the enterprise, the average profit in the industry will result in the deviation of the company's net profit from the average industry value.

We agree with $\mathrm{L}$. Hots that the lack of goodwill value calculation by methods based on the use of surplus profit, medium-size profit and sales volume is the definition of goodwill as additional income, which is not consistent with its interpretation of the amount of intangible assets that is not are reflected in the financial statements of the company [14, p. 187].

Approval of the considered approaches and methods of goodwill evaluation is carried out on the example of the data of the international company "Xoanon Analytics AB" [18] (Table 1). The analysis showed that different methods of the evaluation show an unequal goodwill of the enterprise. The difference is not significant as all methods have shown positive goodwill, but the magnitude of the error suggests that the profitable methods cannot provide the most reliable and prompt information about the goodwill.

Table 1 - Approval of profitability Goodwill estimates on the example of the international company "Xoanon Analytics AB"

\begin{tabular}{|c|c|c|c|}
\hline Method & Formula & Output & Goodwill Value \\
\hline 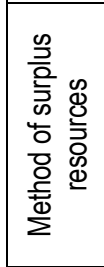 & $\begin{array}{l}\quad \mathrm{GW}=\left(\frac{N I}{\mathrm{RCA}}-T A\right) * W \\
\text { where GW - is goodwill; } N I-\text { net profit; } \\
\text { RCA - profitability of total assets; } T A- \\
\text { the value of total assets; } W-\text { share of } \\
\text { own funds in the structure of liabilities of } \\
\text { the enterprise. }\end{array}$ & $\begin{array}{c}N I-8231 \mathrm{mln} . \text { USD.; } \\
\text { RCA = NI/A = } \\
8231 / 111565=0,073 \\
T A-138537 \mathrm{mln} . \text { dol. } \\
W= \\
78855^{\star} 100 / 138537= \\
69 \%\end{array}$ & $\begin{array}{c}\mathrm{GW}= \\
(8231 / 0,073- \\
111563)^{*} 0,69= \\
=821,39 \mathrm{mln} . \text { USD. }\end{array}$ \\
\hline 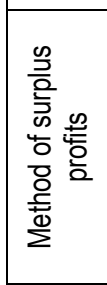 & $\begin{array}{l}\quad \mathrm{GW}=\frac{N O I-N A * R e}{\mathrm{Rg}} \\
\text { where } \mathrm{GW} \text { is goodwill; } \mathrm{NOI}-\text { net operating } \\
\text { income; } \mathrm{NA}-\text { the value of net tangible } \\
\text { assets; } \mathrm{Re}-\text { capitalization of net income } \\
\text { from the main activity; } \mathrm{Rg}-\text { capitalization } \\
\text { factor of intangible assets. }\end{array}$ & $\begin{array}{c}\text { NOI }-10177 \mathrm{mln} . \text { USD } \\
N A=108139-30584= \\
77585 \mathrm{mln} . \text { USD } \\
\operatorname{Re}-13 \% \\
\operatorname{Rg}-14 \%\end{array}$ & $\begin{array}{c}\mathrm{GW}= \\
(10177- \\
\left.\left(77585^{\star} 0,13\right)\right) / 0,14= \\
=649,64 \mathrm{mln} \text {. USD }\end{array}$ \\
\hline 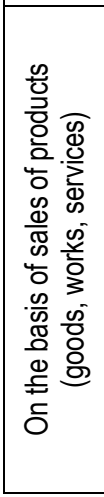 & $\begin{array}{l}\qquad \mathrm{GW}=\frac{N O I-Q f * R \mathrm{q}}{\mathrm{Rg}} \\
\text { where } N O I \text { is the net operating income of } \\
\text { the company. Calculated as gross income } \\
\text { less operating expenses and expenses for } \\
\text { reimbursement (for current repairs); } \\
Q f-\text { the cost of sold products (goods, } \\
\text { works, services); } R \mathrm{q}-\text { medium-term } \\
\text { profitability ratio of sales; Rg - is the } \\
\text { capitalization factor of intangible assets } \\
\text { (the ratio of company profits to the value } \\
\text { of intangible assets shown in the balance } \\
\text { sheet). }\end{array}$ & $\begin{array}{c}\text { NOI }-10177 \mathrm{mln} \text {. USD } \\
Q f-141452 \mathrm{mln} . \text { USD } \\
R \mathrm{q}-3 \% \\
\mathrm{Rg}=10177 / 1300=7,8\end{array}$ & $\begin{array}{c}\mathrm{GW}= \\
(10177- \\
\left.141452^{*} 0,03\right) / 7,8= \\
\mathrm{mln} . \text { USD. }\end{array}$ \\
\hline
\end{tabular}

Sources: Calculated based on: [17]. 
Taking into account the above-discussed methods, the benefits of using a return-based approach are:

- promising, that is, the orientation of accounting users for future results of the company (estimation of goodwill as a generator of future additional revenues);

- suitable for the evaluation of intangible components of goodwill that create an economic effect from their existence;

- it enables to accurately reflect the real value of goodwill in view of current market expectations.

We highlight the main shortcomings of the profitability approach of goodwill assessment:

- lack of the possibility of applying the approach by companies that bear losses of current activity, but in which there are signs of internal goodwill;

- significant dependence of valuation methods on the discount rate, the use of which is always associated with risks;

- a large amount of information to be owned by the company regarding the state of the market and the position of competitors;

- not always sufficient competence and experience of goodwill assessors;

- does not fully take into account the time factor and all the risks inherent in the individual elements of goodwill.

We believe that the proposed methods can be used to verify the correctness of the determination of the value of external goodwill by the balance method. In the event that the goodwill is found to be smaller, it is expedient to write down the difference found at the expense of the period.

Here we will consider an expedient approach to calculating the cost of goodwill. Its essence is to determine the cost of intangible components as a sum of costs for their formation at current prices. The controversial point is that the retrospective nature of the costs may not reflect the current status of goodwill.

The basis of the use of the cost approach is the labour theory of value. The use of this approach is criticized by academics because the retrospective nature does not always allow us to estimate the real value of intangible assets. In the financial accounting system, the expense approach can be applied to any tangible and intangible asset, regardless of its specificity and function. Therefore, we believe that the expense approach is fully justified in using for the estimation of the value of internal goodwill in the context of the selected elements. In addition, a characteristic feature of the cost approach is the identification and quantitative measurement of costs by costing items (personnel training, advertising costs, business relationships). An approach can be used to measure certain elements by capitalizing the costs of creating intangible components of internal goodwill.

An important argument of most researchers is paragraph 51 of IFRS 38, which states that "intrabranded trademarks, titles, titles, customer lists, and other similar content objects should not be recognized as intangible assets" [16]. However, goodwill on an economic substance is a specific intangible asset, as evidenced by the separation of a separate account for its account (account 19 "Goodwill") and the absence of the need for an accrual of depreciation used for all other intangible assets.

In the case of the establishment of an intangible component of the internal goodwill by the enterprise itself, it can not be recognized in accounting, despite the fact that here the cost of its creation can reach a large size. A striking example of this can be the well-known Coca-Cola, Microsoft, Nike, whose brand value is several times taller than the value of the firm's assets. We believe that the current approach does not stand up to criticism, taking into account global business trends and the practice of intangible assets.

The benefits of using a cost-effective approach include:

- general-purpose character, that is, the use of the considered method may be feasible for any of the intangible components of goodwill;

- no need for market information and stock market data.

The disadvantages of a costly approach are to ignore the indicators of profitability, which makes it impossible to track the impact of goodwill on the company's revenue growth, and not taking into account 
relevant market information.

The market approach to measuring goodwill costs involves comparing the valuation object with similar objects existing on the market. For the application of this approach, the existence of certain conditions is mandatory. In particular, in his studies M. Lagarden [4, p. 245] stated that the use of this approach is possible only if there is: sufficient information (of appropriate quality) regarding commercial transactions related to intangible assets of a similar meaning; specific technologies, with which it is possible to make comparisons between comparable objects. However, it is necessary to take into account the fact that the global trend is a gradual increase in the number of smartphones with Internet access, as $59 \%$ of the adult population, according to a global survey conducted by Pew Research Center, owns intelligent telecommunication devices (31\% have regular phones, $10 \%$ no phone) (Figure 1).

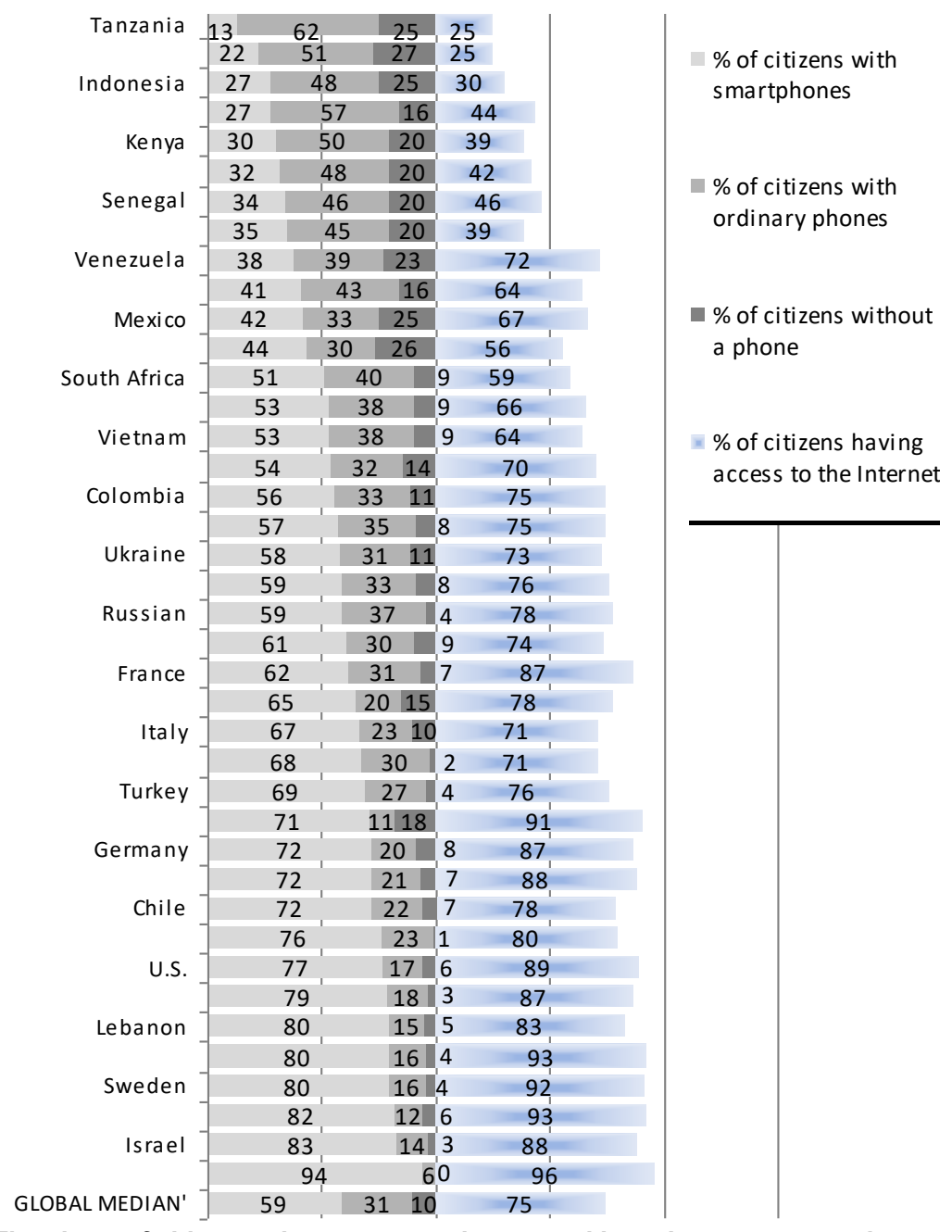

Figure 1 - The share of citizens who use smartphones and have Internet access by country

Sources: calculated based on [6].

in 2018 
Since the fair value determination is based on current market prices, the identification of the market and fair values are often fair. The difference between the values is based on the International Valuation Standards, according to which: market value is the estimated monetary amount at which the asset exchange on the valuation date between the interested buyer and the interested vendor as a result of the commercial transaction would occur after proper marketing, in which each of the parties Acting would be well-informed, economically and without coercion.

Fair value is the estimated price for the transfer of assets or liabilities between specific knowledgeable and interested parties, reflecting the respective interests of each party [16]. Thus, one of the elements of a fair valuation is the definition of market value, which is based on open and public pricing. In other words, a market valuation is carried out by means of a market definition of the value of similar assets or liabilities in a free market with equilibrium demand and supply and conclusion of a commercial agreement, which may not be carried out at the determination of fair value.

In most cases, determining the market value of goodwill without the use of effective market monitoring techniques is a rather abstract category. An accountant who may not be a specialist in the field of material and technical support, market valuation, investment analysis, cannot reliably determine the market value of accounting objects. Similarly, the lack of reliable communication links may result in inaccurate data on the price of an item on the market. There is also a subjectivity of accounting and control specialists in choosing a similar object to compare its value with an appraisable asset or liability. An enterprise accountant or customer assessment can resort to price manipulations and influence the choice of objects for comparison. The necessity of the involvement of an independent auditor or market expert increases the cost of the assessment.

The computer program for evaluating automation through the Internet must contain a web search module. After entering into the search system as much as possible a detailed description of the reference sample, the identification of similar objects is made for the next comparison. From the web search result list, it is expedient to select twenty per cent of the data found with the maximum matching of search phrases. With the automated selection, objects that accidentally fall into search results, obsolete data, and those that have lost their relevance are being removed.

The control sample of evaluation objects is recommended to be transferred to expert examination by specialists who will manually check the compliance with search queries. After verification of the reliability of the automated sample, you can proceed to the definition of the market value of the assets and liabilities of the enterprise.

Evaluation using the computer-communication form of accounting by first is carried out sorting the list of searches by reducing the cost of the found object of accounting on the Internet. Ten per cent of the objects with the maximum and minimum prices are appropriate to discard, which will avoid statistical errors. Objects with speculative or artificially inflated prices are removed. After selection, we can proceed to the determination of the weighted average market value, based on the quantitative and price proposals on the market. The weighted average method gives more reliable data compared with the calculation of the average cost method. That is, if an enterprise needs to evaluate several types of assets of the same type, then it would be advisable to use the weighted average method if the object is evaluated one - the method of determining the average price is more priority.

Popularity is obtained by the method of estimating the cost of replacement, which is based on the definition of the minimum price, which is required to pay for a valuation object with a similar consumer value. In the system of computerized accounting, it is expedient to predict the possibility of searching on the Internet analogies to the evaluation object, which is the equivalent to the used variants. The weighted average minimum price on the market can be used in determining the value of the valuation object.

By a similar algorithm, it is possible to automate the valuation using the recoverable cost method, which is to sum the market costs for creating a new exact copy of the asset being evaluated. Before 
starting an assessment, it is necessary to determine the list of elements that form the full value. Thus, it is expedient to search for information about goodwill on its separate components, but not in general. In other words, it is necessary to carry out automated monitoring of goodwill elements and to generalize costs to determine the cost, which will be the estimated value. When evaluating it is advisable to estimate the incomes and costs of competitors in the market. The use of valuation methods of benefits in income, benefits in costs, benefits in profits in terms of the computer-communication form of accounting allows you to receive information about the financial condition of all business entities that are participants in market relations.

In other words, for the purpose of using a market approach, goodwill value is measured by comparing with the current value of similar transactions relating to such assets in terms of quality, functional purpose, and degree of economic efficiency. In most cases, the price of an intangible asset formed on the current market (average market price) is taken into account.

The disadvantage of applying a market approach to goodwill may be unconfirmed and insufficient transparency of data on the value of intangible components of goodwill.

However, among the advantages of such an approach can be identified as follows:

- a possibility of taking into account functional and consumer features of intangible components of goodwill;

- cost savings and time to carry out the evaluation, since the functions of accounting officers are performed by an automated program;

- use of communication channels helps to optimize information flows;

- higher reliability of the assessment due to the operational reaction to changes in external factors of the enterprise.

Conclusions and directions for further research. The use of computer-communication accounting forms enables us to determine the market value of goodwill without the participation of accounting officers. Through the search on the Internet of analogues of the object of evaluation and calculation of the average weighted price of the object of evaluation can maximize the reliability of the data. The advantages of using this algorithm is that the estimation (revaluation), with an appropriate reflection in the accounting system, can be carried out periodically according to the established algorithm taking into account the external factors of influence on the enterprise (inflation index, stock exchange index, exchange rate, cost of similar market valuation purposes). When developing the software for automating the evaluation, it is advisable to take into account the multiplicity of valuation methods for different measuring instruments, currencies, and prices in order to obtain versatile information for use in financial and managerial accounting.

The market method of goodwill evaluation using the computer-communication accounting form minimizes the costs of material and time resources in conducting valuation works, since a specialized program performs the functions of accountants; optimizes information flows using communications; contributes to increasing the reliability of the assessment due to the constant consideration of external factors of impact on the company. The priority areas for further research should be to conduct an analysis of existing software products for evaluation and proposals for their improvement in order to provide reliable information to investors, owners, and firms management.

\section{References}

Bielawski P. (2016) Value measures in accounting and valuating financial instruments. Actual Problems of Economics, №1(175), 312-322 [in English].

Canning J. B. (1929) The Economics of Accountancy. New York: Ronald Press, 278 p [in English].

Gadawska J. (2011) Effect of Provision on the Valuation of a Company. Equilibrium. Vol. 6. Issue 2, $113-121$ [in English].

Lagarden M. (2014) Intangibles in a transfer pricing context: where does the road lead? International transfer pricing journal, № 2, 331-346 [in English]. 
Miller Louise. (2012). An Internet-based Accounting Information Systems Project. American Journal Of Business Education, 5 (6), 743-752 [in English].

Pew research centre. - Social media use continues to rise in developing countries but plateaus across developed ones. [in English].

Ping H. D., Bao Di (2014) Valuating goodwill of cultural enterprises using wavelet neural network. International journal of $\mathrm{u}$ - and e-Service. Science and Technology, Vol.7,№4., 147-158 [in English].

Tavakolnia E. Makrani S. (2015) Auditor industry specialization and market valuation of earnings and earnings components: empirical evidence from companies listed in Tehran stock exchange Accounting and Finance Research, Vol. 4., 187-195 [in English].

Treidler O. (2015) Why the future of transfer pricing is linked to Improving the valuation of intangibles // Research. [in English].

Vasarhelyi A. Miklos, Kogan Alexander and Tuttle M. Brad. (2015) Big Data in Accounting: An Overview. Accounting Horizons, 29, No. 2, 381-396 [in English].

Wilkin L. Carla, Campbell John, Moore Stephen and Simpson Jason. (2018). Creating value in online communities through governance and stakeholder engagement. International Journal of Accounting Information, 29, 37-58 [in English].

Andryevskyy I. A. (2012) Gudwil: vlyyanuye na itohovoyu stoimost companii [Goodwill: impact on the company's total value]. Byuleten "2K Audyt - Delovye konsultacii / Morison International». - Bulletin "2K Audit - Business Advice / Morison International", 35. - Available at: http://innclub.info/wp- content/uploads/2012/04/\%D0\%91\%D1\%8E\%D0\%BB\%D0\%BB\%D0\%B5\%D1\%82\%D0 \%B5\%D0\%BD\%D1\%8C-\%E2\%84\%96-35.pdf [in Russian].

Blank I. A. (2001) Osnovy investycionnoho menedzmenta [Fundamentals of investment management] (Vols. 1-4). K.: Elha-N, Nyka-centr, V. 1 [in Russian].

Gots L. (2012) Metodyky vyznachennya vartosti gudwily [Methods for determining the goodwill value]. Prometey - Prometey, 1(37), 140-143 [in Ukrainian].

Karpycheva A. A. (2010) Razvutie metodolohyi buhgalterskoho ucheta gudwila v organizaciyah APK [Development of methodology of goodwill accounting in organizations of agroindustrial complex], M., 144-151 [in Russian]..

Mizhnarodnyi standart finansovoi zvitnosti 38 «Nematerialni aktyvy» [International Financial Reporting Standards 38 «Intangible assets»] (2018 January 1). [in Ukrainian].

Ofitsinyi sait miznarodnoi companii "Xoanon Analytics $A B$ » [The official website of the international company «Xoanon Analytics $A B »]$ [in Ukrainian].

Polozhennia (standart) bukhhalters'koho obliku 19 "Ob'iednannia pidpryiemstv», zatverdzhene nakazom Ministerstva finansiv Ukrainy vid 7 lypnia 1999 roku № 163, zi zminamy i dopovnenniamy [Regulation (Standard) 19 "Business Combinations", approved by the Ministry of Finance of Ukraine on July 7, 1999 № 163, with amendments] (1999 July 7). Retrieved from http://zakon4.rada.gov.ua/laws/show/z0499-99 [in Ukrainian].

Puzynya N. Yu. Osobennosty otsenky gudwilla kak stoymosti delovoy reputatsyy firmy [Features of goodwill valuation as the value of a firm's reputation] Imuschestvynnye otnoshenyya v Rossyiskoi federatsii - Property relations in the Russian Federation,2, 41-48 [in Russian].

Samsonov V. Harchenko S. (2004) Kak otsenyt gudwill [How to evaluate goodwill]. Finansovyi dyrektor - Financial director, 2, 144-151 [in Russian].

Travin V.V. (2010) Osoblyvosti orhanizatsii bukhhalters'koho obliku vnutrishn'oho hudvilu iak proiavu sotsial'noho kapitalu na mikroekonomichnomu rivni [Features internal accounting of goodwill as a manifestation of social capital at the micro level] - Visnyk ZhDTU - Bulletin ZhDTU, 2 (52), 192-199 [in Ukrainian].

3.-М. В. Задорожний, д.е.н., професор, Тернопільський національний економічний університет (Україна);

ю. A. Судин, к.е.н., Тернопільський національний економічний університет (Україна);

B. B. Муравський, к.е.н., доцент, Тернопільський національний економічний університет (Україна).

Оцінка гудвілу в управлінні підприємством: інноваційні підходи 3 використанням комп'ютерних та комунікаційних технологій

у статті гудвіл розглядається як особливий вид нематеріального активу, який приносить підприємству додаткові прибутки та сприяє зростанню конкурентоспроможності. Доведено, що управління вартістю гудвілу та можливість достовірно ії оцінити є пріоритетними завданнями менеджерів компанії, а розвиток комп'ютерно-комунікаційної форми обліку вносить нові корективи у способи та методи оцінки нематеріальних активів підприємства. Метою статтіє проведення аналізу існуючих методів оцінки та розгляд принципово нових підходів до використання комп'ютерних технологій в розробці інноваційноі методики визначення вартості гудвілу як сукупності нематеріальних переваг підприемства. У статті використано історикологічний та економіко-математичний методи для аналізу існуючих підходів до оцінки гудвілу, узагальнення та порівняння для обгрунтування використання ринкового підходу з використанням комунікаційних технологій як інноваційного методу оцінки гудвілу. Виявлено переваги та недоліки кожного з актуальних підходів до визначення вартості нематеріального активу. Доведено, що дохідний метод розглядає гудвіл як генератор майбутніх доходів фірми, що дозволяє орієнтувати користувача на майбутні результати компанії, проте при його використанні відсутня можливість провести оцінку наявного гудвілу у підприємств, де спостерігаються збитки у поточній діяльності. Проаналізовано використання витратного методу, який вважається найбільш вживаним, оскільки дозволяє врахувати витрати, що складають вартість активу тає нетрудомістким, 
Z.-M. Zadorozhnyi, Y. Sudyn, V. Muravskyi. Goodwill Assessment in Enterprise Management: Innovative Approaches Using Computer and Communication Technologies

однак неможливість оперативно враховувати ситуацію на ринку та порівнювати нематеріальні переваги з конкурентами $\epsilon$ його недоліком. Зазначено, що недоліком ринкового підходу є недостатня прозорість даних щодо вартості нематеріальних компонентів гудвілу, проте використання комп'ютерних програм та інтернет-технологій, як визначальних факторів у підвищенні оперативності та достовірності проведення оцінки, роблять його найбільш виправданим у сучасних умовах. У статті зроблено висновок, що використання ринкового підходу до оцінки гудвілу сприятиме: мінімізації фінансових та часових ресурсів на здійснення оцінки, оскільки частину функцій здійснюватиме комп'ютерна програма; оптимізації інформаційних потоків, що зумовлюється використанням комунікаційних каналів; підвищенню достовірності оцінки, що пов'язано 3 оперативною реакцією на зовнішні зміни, які впливають на підприємство.

Ключові слова: оцінка, нематеріальні активи, гудвіл, управління підприємствами, інновації, комп'ютерна форма зв'язку бухгалтерського обліку.

Manuscript received: 25.10 .2018

(C) The author(s) 2018. This article is published with open access at Sumy State University. 